\title{
An Investigation Study WiMAX Network Monitoring and Analysis Industrial Quality Management
}

\author{
Haris Yaseen ${ }^{1}$, Dr. Memoona Saeed Lodhi ${ }^{2}$, Dr. Atif Aftab ${ }^{3}$ \\ ${ }^{1,2,3}$ Hamdard University KarachiPakistan
}

\begin{abstract}
The WiMaxclaims to provide mobile broadband coverage, full Strength signal with mobility, portability and tractability till the long distance end point. In this project I use various tools for testing the signal strength with point to point mobility within the WiMax cell. The purpose of this study is to check the reliability and prime functionality minimize the waste (Agile), reduce the defect (Sigma), portability with mobility with the help of KPI,SSR and to provide quality management in IT real world.The objective is to monitoring and analysis of IEEE and WiMax throughout the network in the targeted areas as sample for the test to detect user problem in real world. The Sample test area of Karachi Divide in to two rings with 9 Cluster in between Centrum Cluster is deployed they containing microwave link and the fiber optics. Clusters points are provided for testing 40 in Hyderabad and 30 in Sukkur less than 15 meters of diameter. Various applications are use in the test like Matlab, Real Time Alarm, DU Meter, Portal Element Management System etc. to discuss the Noise Carrier for Ratio of interface \& RSSI, Data rate and modulation schemes.

Keywords: Backhaul $=$ Replacement of wireless from wired, Latency $=$ Delay in system Process by input to illustrate outcome, RSSI= Received Signal Strength Indicator, Stera= Cannot be definable in most of dictionaries , WiMAX = WorldWide Interoperability for Microwave Access Or known as $4 G$ network
\end{abstract}

\section{Introduction}

In the mid 1990's, telecom affiliations built up the thought to utilize settled broadband remote systems for potential last mile answers for give a substitute. Their indicate was pass on a system with dependability of a hardwired structure, while remaining mindful of the adaptability, straightforwardness, and low expenses of a remote system. This headway would in like way go about a flexible framework in support of commercial or institutional backhaul dispersal engineers furthermore would effort in the direction of battle through the rule Internet bearers. Video calling is dreaming more. In the nineteen ninety nine ERICISSON demonstrate the first video call. Where number of services provider facilitate WiMAX, in all of them only four ISP have great fame Pakistan and in these the Wateen has secured top of the most over all in Pakistan's service provider for WiMAX. I do the research study in the direction of authenticate and corroborate WiMAX signals as per standards made by WiMAX forum and IEEE, all the way through region wide population sample with usual different apparatus, applications, antenna and drone with setup vehicle with different parameters as allowed by the standards for remarkable real world. Subscribers can used advanced telephony, surf the internet at super-fast speed, make video calls and watch IP-TV through the comfort and ease afforded by a single connection. The Wateen telecom is the first company in the world to roll-out the Wi-MAX network at a country wide scale. WiMAX is standards-based technology enabling the delivery of last mile wireless broadband access as an alternative to wired broadband like cable or DSL. With globally renowned partners such as Motorola, Cisco and Intel, the stage set to revolutionize the way you use technology! With Wateen'sWi-MAX network you get access to:Broadband internet with up to $2 \mathrm{Mbps}$ dedicated speed.Telephony with over 40 value added features, andfully secured high-speed data networks. Statement of Problem is as investigation study WiMAX network and analysis industrial quality management. What is the signal strength in real life and simulation based scenarios? Is signal are providing as per standard or the service provider claim? Is WiMAX given effective signals in cell till end mile access with mobility and portability? Are the antenna and other nodes are assembled properly or I not assembled proper then what's the effect on the result? Verify the cell shape as per standard or not? Is actual capability provided in real or not? I concentrate on the Wi MAX Network Monitoring investigation in the real world WiMAX systems. The subtle elements of the usage, Monitoring and investigation with Quality of Service in the Wi MAX system engineering will be introduced. It incorporates the meaning of different administration streams characterized by the IEEE 802.16 standard. The restrained elements of the system's usage, Monitoring and examination are exhibited. To investigate the parameters recreation in view of the prevalent system are utilized. Different parameters that decide Quality of Service of genuine use situations and movement streams of uses is broke down. The objective of the study is focused nationwide monitoring WiMAX signals as in real world also compared with standards of WiMAX forum and IEEE standards as well. I focused especially south region cover Sind and Baluchistan rural (country side areas) and urban areas. In this study I used different software and application use Google earth, drone, ping navigation management, MapInfo 
and CPE also others. Use parameters like as jitter, delay, throughput and etc. Mostly researchers are worked on simulation based for real world scenarios and they claimed it's like a real. The uniqueness of my work is real work in real world with WiMax service provider tool and software with nodes of network. DU meter and a NET meter for compression the values as validation.

\section{Introduction}

\section{Methodology}

The era for continuous improvement through 5S, Agile, 6-Sigma to minimize losses enhance quality, mitigate risk, without delay communication till end mile using multiple service of internet and mobile telecom with bespoke application etc. It becomes ease to follow as per standards. The paper is based on study research project for M.Phil, An Investigative study WiMax Network Monitoring and Analysis Industrial Quality Management with improvement of QoS through various real tests and analysis rather than the simulation. Sampling is carried out from the southern region, where the box Karachi is divided into 2 rings (cover / contain complex 9 cluster areas), one connected via a radio link \& eight are linked with optical fibers. One cluster used as interface / bridge between the two metropolitans. Fifty points were tested from original coordinates provided within fifteen meters in Hyderabad, 30 point in Sukkur. In this paper discuss obstacles, constraints, data rate, use of parameters, modulation schemes, SR sheets, KPI and RSSI with greater mobility, portability and accessibility till end mile of WiMAX cell. Many applications and software are used, some elements like portal management system, MATLAB, Real-time \& ELTEK alarm and DU meter net meter etc.

\subsection{Basic Goal of Network Management}

There are generally three basic goals of network management.

- $\quad$ Fault monitoring.

- Account monitoring.

- $\quad$ Performance monitoring.

Fault monitoring refers to the measuring the faults in the network. Fault monitoring deals with the various layers of the network. When a problem occurs, it can be in different layers. Thus, it is important to know which layer is having problem.Account monitoring measures how the user uses the network. The network keeps a record of the devices used by the user. This type of information is used for billing user for network usage and for future network usage. Performance monitoring deals with measure the performance of the network. It measures the time duration in which network does the work. It also measures how slow or fast is the network.

\subsection{Wateen Telecom Limited:}

Wateen'sWi-MAX is standards-based technology enabling the delivery of last mile wireless broadband access as an alternative to wired broadband like cable or DSL. With globally renowned partners such as Motorola, Cisco and Intel, the stage set to revolutionize the way you use technology! With Wateen's Wi-MAX network you get access to:

- $\quad$ Broadband internet with up to $2 \mathrm{Mbps}$ dedicated speed.

- Telephony with over 40 value added features, and

- Fully secured high-speed data networks

Subscribers can used advanced telephony, surf the internet at super-fast speed, make video calls and watch IP-TV through the comfort and ease afforded by a single connection. Wateen Telecom offers a complete range of Telecom and Multimedia services like fixed wireless and mobile telephony, broadband for data, internet and TV/Multimedia along with other value-added services and applications to set the standards for a new era of communication in Pakistan.

\section{Methodology}

Network including wireless and wire line are converging towards mobile broadband allowing for greater mobility providing user experience similar to what a user will have in an office LAN environment. WiMAX the Worldwide Interoperability for Microwave Access, is an telecommunications technology aimed at providing wireless data over long distances in a variety of ways, from point-to-point links to full mobile cellular type access. It is based on the IEEE 802.16 standard which is also called Wireless MAN. Wi-MAX allows a user, for example, to browse the Internet on a laptop without physically connecting the laptop to a wall jack. The name Wi-MAX was created by the Wi-MAX Forum, which was formed in June 2001 to promote conformance and interoperability of the standard. The Forum describes Wi-MAX as a standard-base technology enabling the delivery of last mile wireless broadband access as an alternative to cable and DSL. The Network monitoring is the use of a system constantly to monitor a computer network for slow or failing components that notifies network Engineer about the current situation of the network via email, SMS or alarms. Network monitoring applications are created to collect data for the network management applications. Network monitoring is used to 
monitor different threats from outside and inform the administrator about the threat. It is also monitors problems caused by overload or crashed servers, network connections or other devices. It also includes the monitoring of CPU usage, storage, virus and server proxies.

\section{Instrument developing and construction}

The service provider network is well structured over all in Pakistan and claimed the No. 1 in Pakistan. The biggest network monitored by several tools and documentations. The few of tools or software are also available on internet as web based applications as well as bespoke software available like metacafe, DU Meter and Net Meter for downloading and uploading speed monitoring. Tailored software utilized for signals strength name as $\mathrm{MOTOWI}^{4}$ and $\mathrm{CPE}$ at customer end, the DAP analysis for nationwide. Perform for this research wondering the south region cluster points and base station or available sites around under fifteen (15) meters and take test for. Use drone with receiver and vehicle with WiMAX node connected to network through providing high speed for validate the mobility with portability till the last mile access.

\subsection{Requirement List}

There are many of things, I required for the purposes of the performing this research are as:

a. First of all the tools or software or application.

b. Transportation

c. Access id and password where needed

d. Customers complain report sheets.

e. Work force complains sheet.

f. Problem resolve sheet which have done job.

g. Laptop.

h. Indoor and outdoor antenna.

i. All network nodes.

\subsection{Research Tools / Instruments}

The sampling gather by the Network monitoring is the use of a system constantly to monitor a computer network for slow or failing components that notifies network Engineer about the current situation of the network via email, SMS or alarms. It is used for network management. The purpose of network monitoring is to collect information for the network management. During my study project work at Wateen Telecom the major responsibilities which I gone through with different tools are used for network monitoring sampling such as:

- Motorola Portal EMS Network Topology [Wateen]

- EMS

- Real time alarm viewer and management.

- Statistics storage.

- DU Meter

- Drones

- $\mathrm{CPE}$

- MOTOWI4

- Metacafe

- Network management System

- KPI and SR Reporting Sheets

- Drive Testing.

- Nationwide network Monitoring.

- Call Testing etc.

\section{Population}

The targeted sampling populations are based on the areas or cluster points or base stations where I perform test for project work, which are consist of different cluster points of south region of Pakistan. The service provider for WiMAX, which take in hand on my project in Pakistan mainly have two of integral parts as region as cluster points and metropolitan rings for communication and WiMAX transmission management, integration, improvement and analysis. These are nationwide but important which is discuss in this research intended for network monitoring targeted sampling population are as follow:

a. Nationwide monitoring cover whole country service provider network (end to end).

b. Two (2) metropolitan ring containing nine (9) cluster points contain 84 sites or base stations were tested in Karachi in the region of ten (10) to fifteen (15) meters. 
c. Fifty (50) cluster points provide in Hyderabad, where thirty one (31) were tested in the region of ten (10) to fifteen (15) meters.

d. Thirty (30) cluster points were provided in Sukkur, where seventeen (17) was tested in the region of ten (10) to fifteen (15) meters.

e. South region vise Service Request report cover all cluster points end to end. South region vise Key Performance Indicator report cover all cluster points end to end.

\section{Drive Testing}

Through the DRIVE TEST analysis user validate the real signals strength and comparison with standards as they follow for validation in WiMAX environment. The CPE tool is use or the validation of real world with standards of WiMAX as it is linked with internet access. The parameters are playing significant role to evaluate or observe the performance of it.

- Parameter.

- Frequency.

- RSSI

- CNIR

- Modulation Techniques.

- Preamble Index.

- Data Rates (With the help DU Meter)

- Data Rates (With the help Net Meter)

\subsection{Drive Test Analysis:}

For Hyderabad Field Points

During study project Field work, I analysis and observe coverage issue nodes tested for ATP at Hyderabad with various ends. My observation is also focuses to comparison at all points signal strength values with their standards values. The points or Base Stations were tested around less than 15 meters radius but in few cases may be more.

\section{For Sukkur Field Points}

Taken as a whole the 35 points were provided by authority to me for my project work for validation and observation. Observed received signals strength lees or equal fiteen meters diameter from original coordinate.

\section{For Karachi Network}

Karachi is a metropolitan area so it's handling as rings holding clusters through less than 100 sites are connected. Fewer cluster links with one to other through fiber and only DHA cluster connected through Microwave Link from Business Avenue cluster.

\section{Network Monitoring}

The monitoring of the network throughout countrywide DAP weather status check and the site up or down with the help of PEMS software.

\section{SR Reporting Sheet}

Under then monitoring of network if status downs of any of sites then automatically a request generated. In case request is not generate then admin or user call to service provider for generate the request which helping to maintain service request sheet daily.

\section{KPI Reporting Sheet}

KPI sheet maintain by service provider staff on daily basis also audited it and the KPI sheet based on the customers faces problem in WiMAX for static history for improvement and betterment.

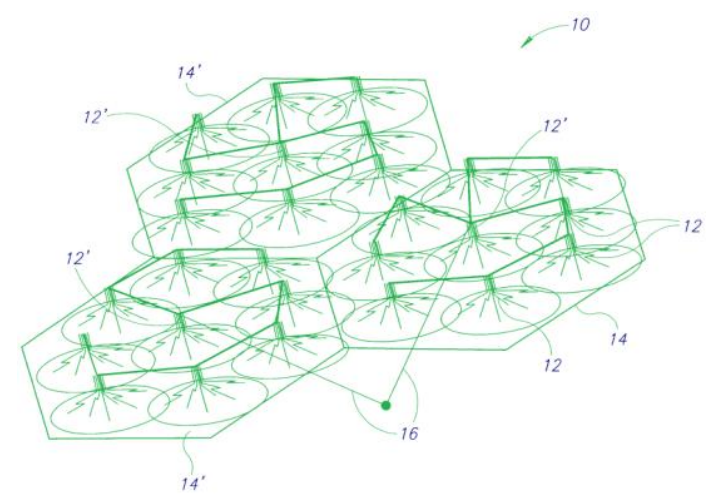

Reference: Standard Cell for WiMAX by WiMAX Forum and IEEE 


\section{Result and Analysis}

\section{FINDINGS}

Karachi is covered by two rings and cluster points in the rings rather than hexagonal shaped cell domain as defined in standards for every BS and MS domain. Due to the road access issue in different areas or cities of south region are not reached able also unavailable of security is biggest issue, law and order situations and the location is not urbanize as counterpart of the metropolitan areas. In Korangi cluster point found weak signals or packet lost in almost throughout the cluster points. I can observe the poor signals over their as comparatively the other part of metropolitan area or Karachi. The distance from the base station may one of the fundamental reasons of it. Huge amount of variation found in CINR in modulation scheme in the same cluster points. Observed Received Signals Strength Indicators also validate the Korangi cluster points comparatively not equal or better than other cluster points especially the inherit micro wave access link cluster too. Due to fields and crops in Korangi cluster points are really effected on received signals, also the vanishing the multi path transmission of signals cause by the factual topography reason. In the south region most of the point was tested around 10 to 15 meters from the original coordinates. The received signals level is highly affected by flora and obstacles. Some of the cluster points were tested around 15 to 20 meters from the original coordinates in Sukkur area. The highly affected by Obstacles at received signals level in Sukkur cluster points.

\subsection{Key Points during ATP Field in Hyderabad:}

Most of the pointy were tested around 10 to 15 meters from the original coordinates.

The received level is highly affected by Vegetation and Obstacles.

\subsection{DRIVE TEST Analysis of Hyderabad Field Points:}

During Field ATP at Hyderabad, I saw that in most points we get different signal strength values than the original values, but in most cases we get a much better coverage and much better data rates then the calculated values. Overall 50 points were provided. Where 31 points were tested on which the CPE was camped. 17 points were Inaccessible due to road access issue and only on 2 points the CPE was unable to Camped.

\subsection{Key Points During Field ATP in Sukkur:}

Few of the point were tested around 15 to 20 meters from the original coordinates. Most of the points were tested around 10 to 15 meters from original coordinates. The received level is highly affected by Obstacles.

\subsection{DRIVE TEST Analysis of Sukkur Field Points:}

Overall 30 points were provided.

17 points were tested on which the CPE was Camped.

13 points were Inaccessible due to road access issue.

\subsection{Key Points During two Field ATP in Karachi:}

Hence by comparing the two clusters of Karachi i.e. Korangi Router cluster and Business Avenue cluster through graphical representation we observe that Business Avenue Cluster have a good coverage and signal strength as most of the points are on open location. Some of the key factors from which you can differentiate the two clusters are as follows:

In Korangi cluster some of the points are not accessible due to road access issue as the location is not so much urbanized.

By observing modulation scheme parameter Business Avenue cluster got almost greater modulation and coding scheme as most of the points of Korangi cluster are at more distance from base station than Business Avenue cluster.

Carrier to interference noise ratio varies according to modulation scheme means greater the modulation scheme greater will be its CINR value. This can be clearly seen to the above chart.

Through RSSI (Received Signal Strength Indicator) value the coverage of any network can be evaluated hence by comparing the RSSI values of two different clusters we can observe that Business Avenue cluster has a good coverage.

Some of the factors from which the coverage of the network varies are fast fading. Due to terrain we get more reflected signal i.e. multi path propagation of signals.

Hence due to obstacle and vegetation the received signal is highly affected.

\section{RECOMMENDATIONS / SUGGESTIONS}

\subsection{Integration:}

Vertical integration in the technology of microwave are interconnects Multi level as hybrid topology. On the bases of this providing like new canvas to draw multiple or several region of flat grow response in local area of 
network for potential effort. There are many of domains open as for future strategic work with per early planning \& document work need with quality of service for $5 \mathrm{G}, 6 \mathrm{G}$, and $7 \mathrm{G}$ off course LTE in metropolitan areas of Pakistan as well as country side areas. It requires as per standard or developing new standard as demographic bases of Pakistan or other country where these technology are away, far away or in pipelines.

\subsection{Video Streaming:}

Due to expansion of multiple TV channels, IP TVs, Social media \& social media channels are demanding without delay end to end packet transferring through WiMAX without packet loss. It's hard to accurate but can mitigate. In this use appropriate integrated algorithm facilitate hybrid topology, No extra MAC enable for under the table solutions, MAC filter are use, no foreign user to prevent the hacker limited a few amount of guest allow with pre define time slot base on multiplexing. User datagram protocol with MAC filter for user who allow by the authority will given better result but it need more work on ground level. The nodes which use for UDP are must be QC passed with fault free electrical or mechanical overall engineering work. When assembled then they proper assembled no lacking in it for better result. Design must be prevent the draw effect of high windy or mitigate the risk of packet loss due to swiftness of wind as well as delay in packets or buffering. The end user has highly demanded one click result beyond the limitation with greater portability.

\subsection{Antenna installation on high rise buildings:}

If the deployment of antenna and other transmitting WiMAX nodes at heavy windy areas effect on signals, so in this regard give selecting strapping structures, mounting antennas in high or good quality with flexible proper fixed can alleviate or mitigate the risk.

\subsection{Effect of pollution on WiMAX:}

The gigantic problem or challenge for metropolitan areas is pollution, whenever Karachi is the five most polluted city of the world in the year 2016. Here number of contamination like noise, dust etc also face heat wave (high temperature), smog and smoke, where the garbage along streets green belts and grounds which generate toxic gasses. The deployment of nodes for WiMAX, The question is over the entire can affect on the signals of WiMA?

The answer is "Yes" and "No" both.

In condition of "Yes" do not designee proper antennas. The Engineering mistakes in it for the relevant frequency.Not proper mount. In the condition of "No"The antennas designee is proper for relevant frequencies. No engineering mistakes or malfunction in it and if it's proper mount as per standard.

\subsection{Security concern for future and current implementation:}

Whatever the technology is old or new the issue of the era is security as well as in software, applications, networks and transformation of data or data in bank. Every new sun rise technology meets newer susceptibility. I purposed to build up are for WiMAX additional efficient and secured network.Mode must integrate every after random period decided by experts of organization.Must be developed secure handshaking, especially for new neighbor found.Message management must be used with control like as other technologies available in market today or the message management need to integrate till more secure.The $R \& D$ department already in the way of continues improvement for

\section{Figures and Tables}

TABLE 1

\begin{tabular}{|l|l|l|l|l|l|l|l|}
\hline Name & frequency & Preamble Index & RSSI & CINR & Speed UL & Mod DL & Mod UL \\
\hline KHI1 & 3460.75 & 20 & -88 & 9 & $190 \mathrm{Kbps}$ & QPSK & QPSK \\
\hline KHI2 & 3460.75 & 20 & -64 & 26 & $1.38 \mathrm{Mbps}$ & 64 QAM & 16 QAM \\
\hline KHI3 & 3560.75 & 49 & -58 & 28 & $1.38 \mathrm{Mbps}$ & 64 QAM & 16 QAM \\
\hline KHI4 & 3492.25 & 86 & -78 & 16 & $1.98 \mathrm{Mbps}$ & 16 QAM & 16 QAM \\
\hline KHI5 & 3492.25 & 20 & -61 & 28 & $369 \mathrm{Kbps}$ & 64 QAM & QPSK \\
\hline KHI6 & 3592.25 & 27 & -85 & 13 & $210 \mathrm{Kbps}$ & QPSK & QPSK \\
\hline KHI7 & 3592.25 & 23 & -82 & 10 & $223 \mathrm{Kbps}$ & QPSK & QPSK \\
\hline KHI9 & 3560.75 & 49 & -86 & 14 & $112 \mathrm{Kbps}$ & QPSK & QPSK \\
\hline KHI10 & 3592.25 & 27 & -63 & 24 & $1.38 \mathrm{Mbps}$ & 64 QAM & 16 QAM \\
\hline KHI11 & 3560.75 & 57 & -72 & 21 & $447 \mathrm{Kbps}$ & 64 QAM & 16 QAM \\
\hline KHI12 & 3460.75 & 28 & -81 & 19 & $503 \mathrm{Kbps}$ & 64 QAM & 16 QAM \\
\hline KHI13 & 3460.75 & 24 & -93 & 9 & $314 \mathrm{Kbps}$ & QPSK & QPSK \\
\hline KHI14 & 3492.25 & 82 & -61 & 28 & $876 \mathrm{Kbps}$ & 64 QAM & QPSK \\
\hline KHI15 & 3492.25 & 82 & -80 & 18 & $787 \mathrm{Kbps}$ & 16 QAM & QPSK \\
\hline KHI16 & 3592.25 & 19 & -84 & 11 & $110 \mathrm{Kbps}$ & QPSK & QPSK \\
\hline KHI18 & 3560.75 & 61 & -86 & 13 & $670 \mathrm{Kbps}$ & 16 QAM & QPSK \\
\hline KHI19 & 3560.75 & 53 & -79 & 18 & $1.21 \mathrm{Mbps}$ & 16 QAM & 16 QAM \\
\hline KHI20 & 3460.75 & 16 & -96 & 8 & $189 \mathrm{Kbps}$ & 64 QAM & QPSK \\
\hline
\end{tabular}


(Reference: Real Signals Coverage Sheet for Wateen Karachi Network)

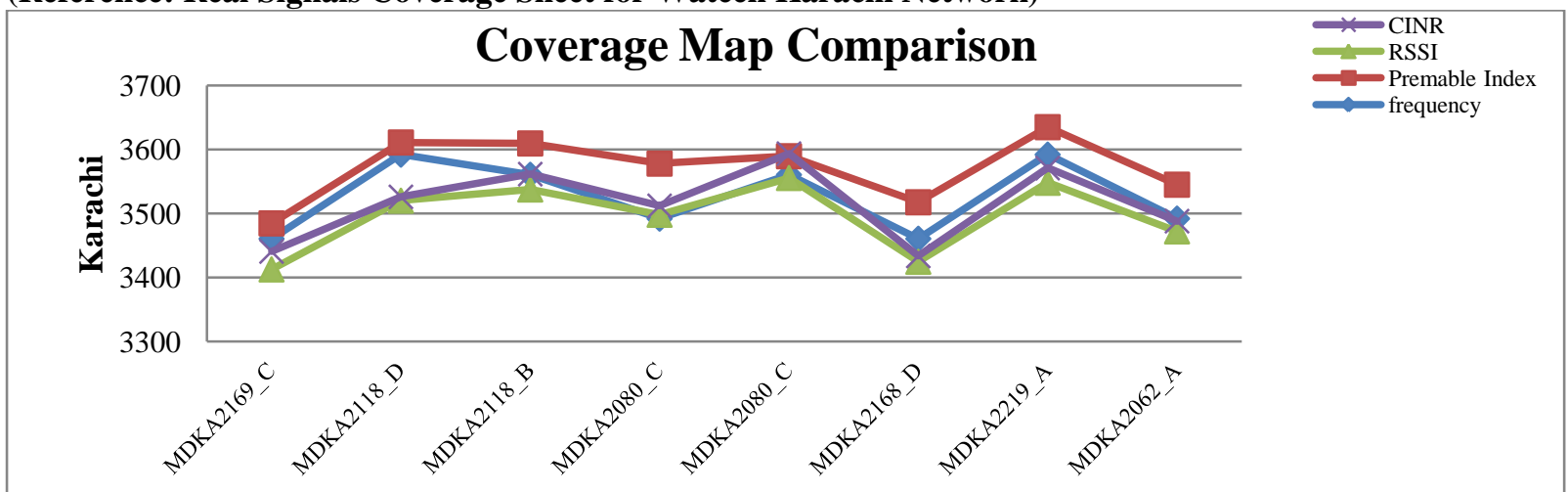

(Reference: Signals Coverage Comparison on the Bases of Sheet forWateen Telecom Karachi Network)
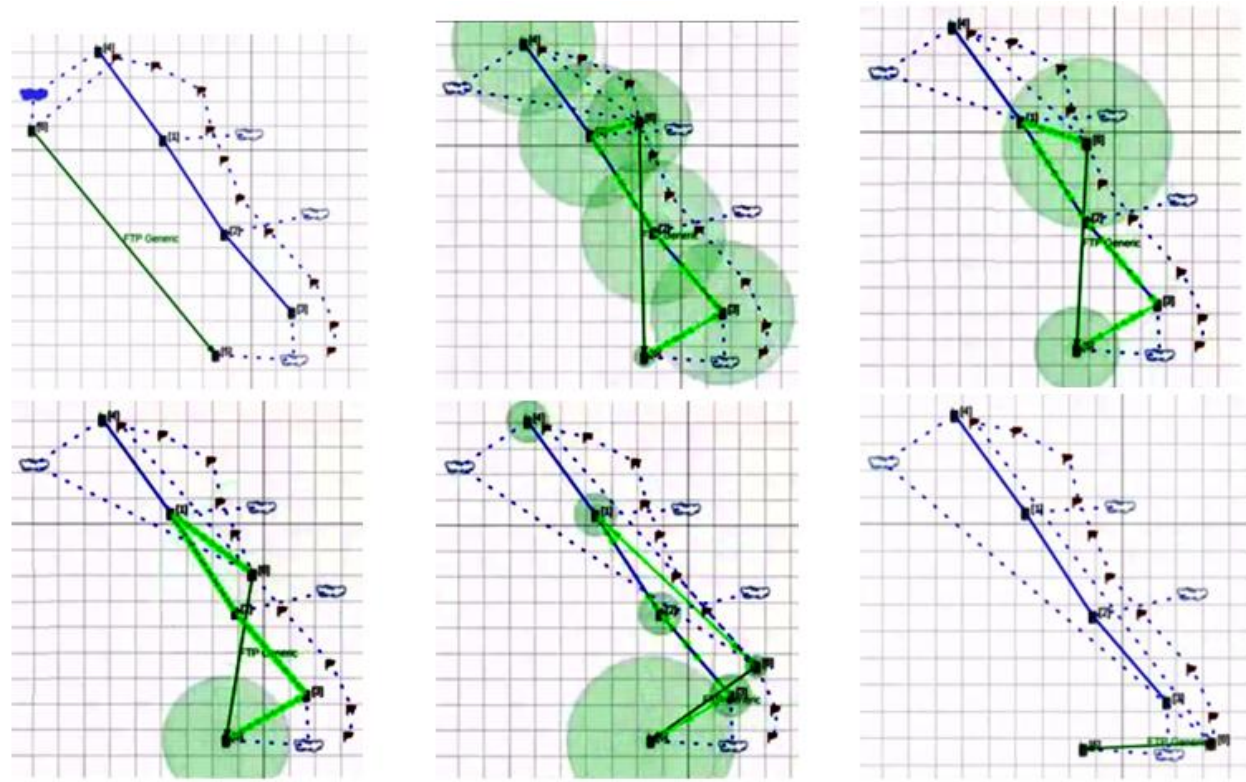

Reference: Real PING Navigation through NTM System South Field Cluster Points at Wateen Network

Coverage Map

DT Analysis Hyderabad Field Cluster

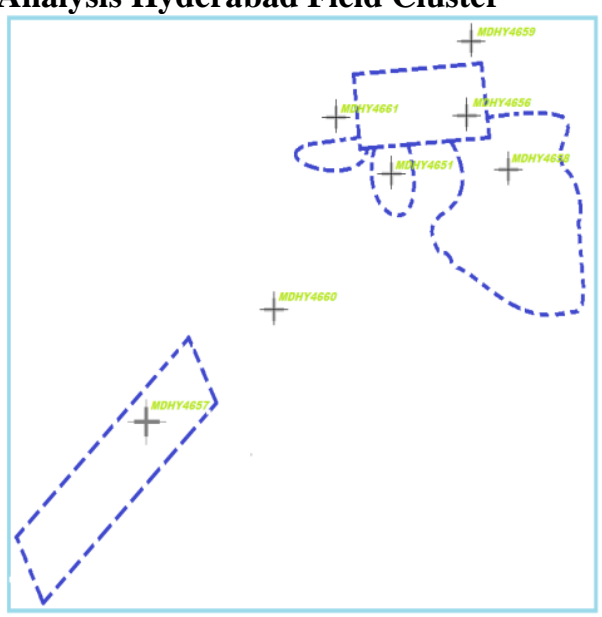

Reference: Real Coverage Map Based on Drive Testing Analysis of Hyderabad Field Cluster Points of Wateen Network Telecom for WiMAX Service Provider
DT AnalysisSukkur Field Cluster Points

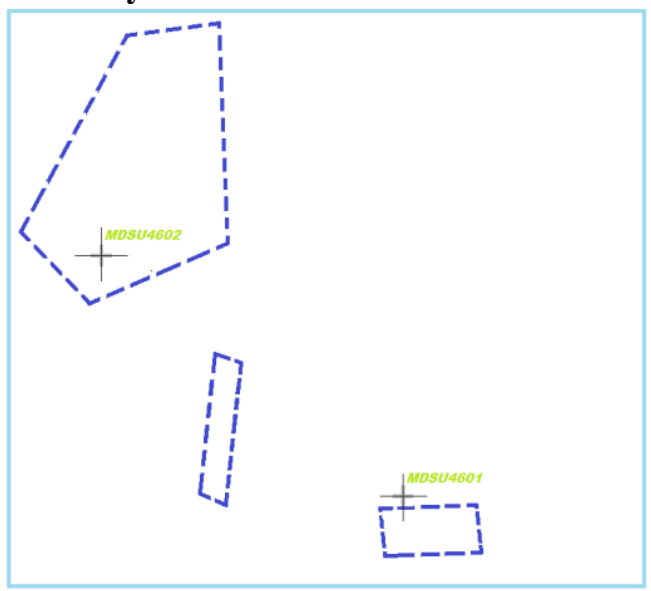

Reference: Real Coverage Map Based on Drive Testing Analysis of Sukkur Field Cluster Points of Wateen Network Telecom for WiMAX Service Provider 


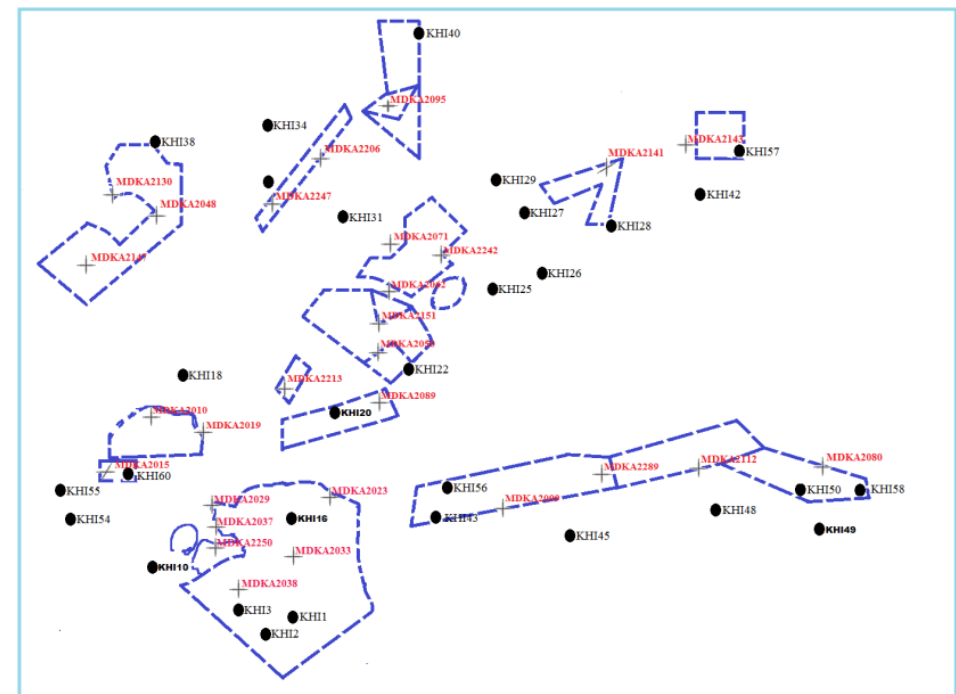

Reference: Real Wateen Telecom Drive Testing snap shot for cluster point Korangi and cluster point Business Avenue Karachi Network from Drive Testing Application

TABLE 2

\begin{tabular}{|c|c|c|c|c|c|c|c|c|c|c|c|c|c|c|c|c|c|}
\hline S.No & Name & Longitude & Latitude & Parent Sector & Frequency & \begin{tabular}{|c} 
Premable \\
Index
\end{tabular} & RSSI & CINR & $\begin{array}{c}\text { Modulation } \\
\mathrm{DL}\end{array}$ & $\begin{array}{c}\begin{array}{c}\text { Modulation } \\
\text { UL }\end{array} \\
\end{array}$ & Speed UL & Speed DL & Latency & Jitter & Disconnection & $\begin{array}{l}\text { Longitude } \\
\text { (If Changed) } \\
\end{array}$ & \begin{tabular}{|c|}
$\begin{array}{c}\text { Latitude } \\
\text { (If Changed) }\end{array}$ \\
\end{tabular} \\
\hline $\begin{array}{l}\text { KORANGI } \\
95 \mid \text { KH195 }\end{array}$ & KH195 & 67.1992 & 24.8553 & MDKA2118_D & 3592.25 & 19 & -91 & 6 & QPSK & QPSK & $222 \mathrm{Kbps}$ & $410 \mathrm{Kbps}$ & 450 & 230 & 0 & No Chaged & No Chaged \\
\hline 96 & KHI96 & 67.2067 & 24.8443 & MDKA2118_B & 2580.75 & 49 & -72 & 24 & 64 QAM & 16 QAM & $336 \mathrm{Kbps}$ & $2.4 \mathrm{Mbps}$ & 68 & 76 & 0 & No Chaged & No Chaged \\
\hline 98 & KHI98 & 67.1491 & 24.8274 & MDKA2104_B & 60.75 & 61 & -1 & - & & - & - & & - & & 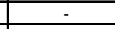 & Camping Issue & No Chaged \\
\hline 102 & $\begin{array}{ll}\mathrm{KH} 102 \\
\end{array}$ & 67.2248 & 24.8345 & MDKA2369_A & 660.75 & 28 & -61 & 22 & 64 QAM & 16 QAM & $1.03 \mathrm{Mbps}$ & $1.9 \mathrm{Mbps}$ & 69 & 72 & 0 & No Chaged & No Chaged \\
\hline \begin{tabular}{|l|l|}
174 \\
\end{tabular} & KHI174 & 67.2441 & 24.8608 & MDKA2371_A & 3460.75 & 16 & -75 & 24 & 64 QAM & 16 QAM & $1.12 \mathrm{Mbps}$ & $2.56 \mathrm{Mbps}$ & 366 & 110 & 0 & No Chaged & No Chaged \\
\hline 98 & KHI98 & 67.2351 & 24.8522 & MDKA2080_A & 3460.75 & 20 & -73 & 8 & QPSK & QPSK & $334 \mathrm{Kbps}$ & $550 \mathrm{Kbps}$ & 58 & 76 & 0 & No Chaged & No Chaged \\
\hline
\end{tabular}

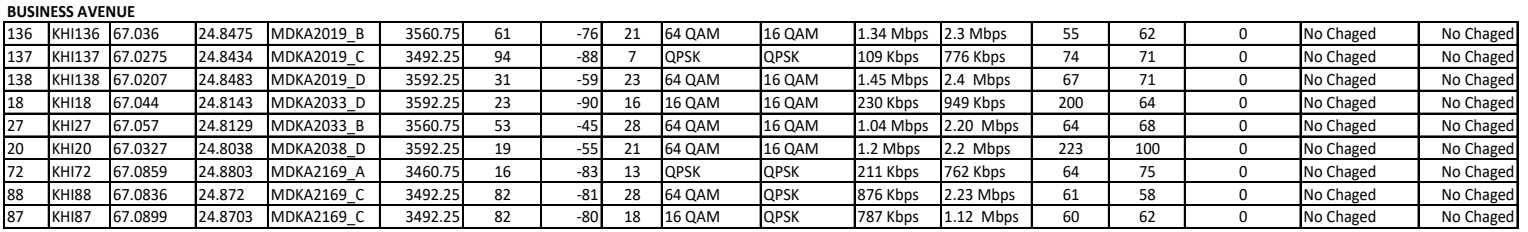

Reference: Real Wateen Telecom Drive Test comparison sheet snap shot for cluster point Korangi and cluster point Business Avenue Karachi Network from Drive Testing Application

TABLE 3

\begin{tabular}{|c|c|c|c|c|c|c|}
\hline Combinations & Alarm Detail & Relay I & Relay II & Relay III & Relay IV & AVR \\
\hline 1 & Normal Operation & No & No & No & No & No \\
\hline \multirow[t]{3}{*}{2} & Battery Fuse & Yes & No & No & No & No \\
\hline & Load Fuse & Yes & No & No & No & No \\
\hline & Critical Rectifier Fail & Yes & No & No & No & No \\
\hline \multirow[t]{2}{*}{3} & HIGH Battery Voltage & No & Yes & No & No & No \\
\hline & LOW Battery Voltage & No & Yes & No & No & No \\
\hline \multirow[t]{3}{*}{4} & 1 Rectifier Fall Alarm & No & No & Yes & No & No \\
\hline & Battery Symmetry Alarm & No & No & Yes & No & No \\
\hline & High Temperature & No & No & Yes & No & No \\
\hline 5 & Air Con & No & No & No & Yes & No \\
\hline 6 & AVR & No & No & No & Yes & Yes \\
\hline 7 & Status Pal & Yes & Yes & Yes & Yes & Yes \\
\hline
\end{tabular}

$\begin{array}{ll}\text { RELAY I } & \text { Critical } \\ \text { RELAY II } & \text { Major } \\ \text { RELAY III } & \text { Minor } \\ \text { RELAY IV } & \text { Air Con }\end{array}$

AVR AVR

Reference: Real world ELTEK alarms from Wateen network portal 
An Investigation Study WiMAX Network Monitoring And Analysis Industrial Quality Management

TABLE 4

\begin{tabular}{|c|c|c|c|c|c|}
\hline SR No. & Priority & Case Title & Open Time & $\begin{array}{l}\text { Current } \\
\text { Status }\end{array}$ & RCA / Comment \\
\hline 2203951 & $\mathrm{P} 4$ & $\begin{array}{l}\text { KAR HYD } 01 \text { X SITE NVIP } \\
\text { MNHY4653 - Site is Down }\end{array}$ & $\begin{array}{l}\text { Aug, } 04-2015 \\
12: 28: 23\end{array}$ & Resolved & $\begin{array}{l}\text { Due to power fluctuations,BCU power } \\
\text { cable was short circuited Cable was rep }\end{array}$ \\
\hline 2203975 & P3 & $\begin{array}{l}\text { KHI NSA Packet-Korangi } \\
\text { router has environeental Alarm }\end{array}$ & $\begin{array}{l}\text { Sep, } 17-2015 \\
16: 30: 43\end{array}$ & $\begin{array}{l}\text { Awaiting } \\
\text { LOAcot } \\
\text { Team }\end{array}$ & \\
\hline 2203985 & P3 & $\begin{array}{l}\text { KHI NSA Packet-7613 touter } \\
\text { has environeental Alarm }\end{array}$ & $\begin{array}{l}\text { Sep, } 28-2015 \\
17: 30: 43\end{array}$ & $\begin{array}{l}\text { Awaiting } \\
\text { LOAcct } \\
\text { Team }\end{array}$ & \\
\hline 2203975 & P3 & $\begin{array}{lrr}\text { KHI } & \text { NSA } & \text { Packet-Korangi } \\
\text { router } & \text { has } & \text { environemental } \\
\text { Alarm } & & \\
\end{array}$ & $\begin{array}{l}\text { Oct, } 20-2015 \\
23: 02: 51\end{array}$ & $\begin{array}{l}\text { Awaiting } \\
\text { Customer }\end{array}$ & \\
\hline 2204073 & $\mathrm{P} 4$ & $\begin{array}{l}\text { KAR HYD NVIP 01X Sector } \\
\text { MNHY4167-Sector D is in } \\
\text { Dormant State }\end{array}$ & $\begin{array}{l}\text { Oct, } 22-2015 \\
17: 08: 23\end{array}$ & Resolved & $\begin{array}{l}\text { RCA Site controlled card has been } \\
\text { replaced Sector is now up }\end{array}$ \\
\hline 2193856 & $\mathrm{P} 4$ & $\begin{array}{l}\text { KHI P4 MDKA2147 } \\
\text { accessible from NOC }\end{array}$ & $\begin{array}{l}\text { Nov, 20 } \\
\text { 19:08:23 }\end{array}$ & $\begin{array}{l}\text { Case } \\
\text { Closed }\end{array}$ & $\begin{array}{l}\text { Closing case after } \\
\text { confirmation }\end{array}$ \\
\hline 2195573 & $\mathrm{P} 2$ & $\begin{array}{l}\text { KHI P2 SA MDKA 2255- } \\
\text { Sector D is not accessible }\end{array}$ & $\begin{array}{l}\text { Dec, } 13-2015 \\
\text { 18:09:03 }\end{array}$ & $\begin{array}{l}\text { Case } \\
\text { Closed }\end{array}$ & $\begin{array}{l}\text { Sector was UP Services were ok Only } \\
\text { loss of visibility }\end{array}$ \\
\hline 2197159 & P3 & $\begin{array}{l}\text { KHI P3-Data rate } \\
\text { Karachi-Lahore } \quad \& \text { Karachi- } \\
\text { Islamabad VPN }\end{array}$ & $\begin{array}{l}\text { Dec, } 27-2015 \\
20: 30: 43\end{array}$ & $\begin{array}{l}\text { Case } \\
\text { Closed }\end{array}$ & $\begin{array}{l}\text { Frequency was changed from Lahore } \\
\text { end. End to End conectivity was } \\
\text { checked }\end{array}$ \\
\hline 2201925 & $\mathrm{P} 4$ & $\begin{array}{l}\text { KAR HYD } 02 \text { X SITES NVIP } \\
\text { MDHY4651 MDHY 4658- } \\
\text { Sites are not accessible from }\end{array}$ & $\begin{array}{l}\text { Jan, } 19-2016 \\
\text { 18:08:23 }\end{array}$ & Resolved & $\begin{array}{l}\text { No repetitive Alarm Reported at the } \\
\text { sites }\end{array}$ \\
\hline 2202550 & $\mathrm{P} 4$ & 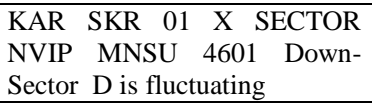 & $\begin{array}{l}\text { Jan, } 19-2016 \\
20: 02: 51\end{array}$ & Resolved & $\begin{array}{l}\text { No repetitive Alarm Reported at the } \\
\text { sites }\end{array}$ \\
\hline 2203704 & $\mathrm{P} 4$ & $\begin{array}{l}\text { KAR KAR 01 X SECTOR } \\
\text { NVIP MDKA2155-Sector C is } \\
\text { Down }\end{array}$ & $\begin{array}{l}\text { Feb, } 14-2016 \\
16: 08: 23\end{array}$ & Resolved & $\begin{array}{l}\text { APDiag was run and sectors were } \\
\text { reconfigured }\end{array}$ \\
\hline 2199304 & $\mathrm{P} 4$ & $\begin{array}{l}\text { KAR P4 Down-MDKA2128 } \\
\text { Sector B is not accessible from } \\
\text { NOC }\end{array}$ & $\begin{array}{l}\text { Apr, } 18-2016 \\
13: 45: 43\end{array}$ & $\begin{array}{l}\text { Case } \\
\text { Closed }\end{array}$ & $\begin{array}{l}\text { Modem was in rolling After swapping } \\
\text { the modem the sector is UP }\end{array}$ \\
\hline 2200743 & $\mathrm{P} 4$ & 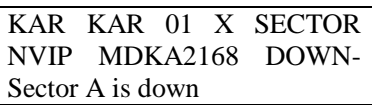 & $\begin{array}{l}\text { May, } 18-2016 \\
\text { 20:09:03 }\end{array}$ & $\begin{array}{l}\text { Case } \\
\text { Closed }\end{array}$ & $\begin{array}{lll}\begin{array}{l}\text { Dupliucate SR, } \\
\text { addressing this issue }\end{array} & \text { SR2200920 is }\end{array}$ \\
\hline 2200920 & $\mathrm{P} 4$ & 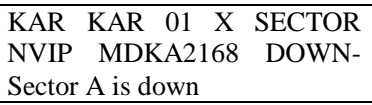 & $\begin{array}{l}\text { May, } 18-2016 \\
17: 38: 13\end{array}$ & $\begin{array}{l}\text { Case } \\
\text { Closed }\end{array}$ & Sector is UP after replacing the RF head \\
\hline 2200953 & $\mathrm{P} 4$ & $\begin{array}{l}\text { KAR KAR 01 X SECTOR } \\
\text { NVIP HUB10 DOWN-Sector } \\
\text { D is down }\end{array}$ & $\begin{array}{l}\text { Jun, } 07-2016 \\
09: 12: 52\end{array}$ & $\begin{array}{l}\text { Case } \\
\text { Closed }\end{array}$ & Sector is UP after replacing the RF head \\
\hline 2201205 & $\mathrm{P} 4$ & $\begin{array}{l}\text { KAR KAR } 02 \text { X SECTORS } \\
\text { NVIP MDKA2023 DOWN- } \\
\text { Sector A.B is down }\end{array}$ & $\begin{array}{l}\text { Jun, } 22-2016 \\
14: 38: 13\end{array}$ & $\begin{array}{l}\text { Case } \\
\text { Closed }\end{array}$ & $\begin{array}{l}\text { Sectors were down due to fiber } \\
\text { breakage. }\end{array}$ \\
\hline 220703 & $\mathrm{P} 4$ & $\begin{array}{l}\text { KAR KAR 01 X Site NVIP } \\
\text { MDKA2033 DOWN- } \\
\text { MDKA2033 is not accessible }\end{array}$ & $\begin{array}{l}\text { Aug, } 11 \quad-2016 \\
16: 45: 22\end{array}$ & $\begin{array}{l}\text { Case } \\
\text { Closed }\end{array}$ & $\begin{array}{l}\text { Site went down due to Activity going } \\
\text { on by SI. It came UP after reloading }\end{array}$ \\
\hline 220565 & $\mathrm{P} 4$ & $\begin{array}{l}\text { KHI P4 Down-MDKA2196_A } \\
\text { is inaccessible from NOC }\end{array}$ & $\begin{array}{lr}\text { Aug, } 17 & -2016 \\
16: 38: 13 & \\
\end{array}$ & $\begin{array}{l}\text { Case } \\
\text { Closed }\end{array}$ & $\begin{array}{l}\text { RF head was replaced during the } \\
\text { activity Sector is now UP. }\end{array}$ \\
\hline 2204292 & P3 & $\begin{array}{l}\text { KHI KHI COMPLT VOL VO } \\
\text { INT MDKA2219-CPE hang } \\
\text { issue }\end{array}$ & $\begin{array}{l}\text { Oct, } 10-2016 \\
12: 12: 52\end{array}$ & $\begin{array}{l}\text { Awaiting } \\
\text { LOAcct } \\
\text { Team } \\
\end{array}$ & \\
\hline 2204296 & P3 & $\begin{array}{l}\text { KAR NSA PACKET-Karachi } \\
\text { Ring } 1 \text { is in protection state }\end{array}$ & $\begin{array}{l}\text { Oct, } 14-2016 \\
10: 12: 52\end{array}$ & $\begin{array}{l}\text { Case } \\
\text { Closed }\end{array}$ & RCA Fiber Cut \\
\hline 2204285 & P3 & $\begin{array}{lrr}\text { KHI KHI } & \text { COMPLT } & \text { Bank } \\
\text { AlFalah } & \text { Ltd } & \text { VPN } \\
\text { MDKA2245-CAMP DECAMP } \\
\text { Issue }\end{array}$ & $\begin{array}{l}\text { Oct, } 24-2016 \\
22: 30: 43\end{array}$ & $\begin{array}{l}\text { Awaiting } \\
\text { Customer }\end{array}$ & \\
\hline
\end{tabular}

\section{SR Reporting Sheet}

TABLE 5

\begin{tabular}{|c|c|c|c|c|c|c|}
\hline Case ID & Priority & Site ID & Opening Date & Status & RCA/ Comments & Restoration Time \\
\hline 2197213 & $\mathrm{P} 4$ & MDKA2087 & $\begin{array}{l}\text { Aug, } 03 \quad-2015 \\
10: 28: 23\end{array}$ & Closed & $\begin{array}{l}\text { Modems were in } \\
\text { rolling and site was } \\
\text { re-commissioned }\end{array}$ & $\begin{array}{l}\text { Aug-03-2015 } \\
11: 45: 43\end{array}$ \\
\hline
\end{tabular}


An Investigation Study WiMAX Network Monitoring And Analysis Industrial Quality Management

\begin{tabular}{|c|c|c|c|c|c|c|c|}
\hline & & & & & & aggregate & \\
\hline 2193856 & $\mathrm{P} 4$ & MDKA2147 & $\begin{array}{l}\text { Aug, } 24 \\
13: 28: 23\end{array}$ & - 2015 & Closed & $\begin{array}{l}\text { Closing case after } \\
\text { customer } \\
\text { confirmation }\end{array}$ & $\begin{array}{l}\text { Aug-24-2015 } \\
14: 45: 43\end{array}$ \\
\hline 2195072 & $\mathrm{P} 4$ & MDKA2011 & Sep, $16-2015$ & $14: 28: 23$ & Closed & $\begin{array}{l}\text { ODU was faulty and } \\
\text { hence replaced }\end{array}$ & $\begin{array}{l}\text { Sep-16-2015 } \\
15: 45: 43\end{array}$ \\
\hline 2195013 & $\mathrm{P} 4$ & MDKA2066 & Sep, $29-2015$ & $22: 09: 03$ & Closed & $\begin{array}{l}\text { There was an issue } \\
\text { with the backhaul } \\
\text { IDM got stuck }\end{array}$ & $\begin{array}{l}\text { Sep-29-2015 } \\
00: 02: 51\end{array}$ \\
\hline 2195013 & $\mathrm{P} 4$ & MDKA2228 & Oct, $05-2015$ & 23:09:03 & Closed & $\begin{array}{l}\text { There was an issue } \\
\text { with the backhaul } \\
\text { IDM got stuck }\end{array}$ & $\begin{array}{l}\text { Oct-05-2015 } \\
01: 02: 51\end{array}$ \\
\hline 2195013 & $\mathrm{P} 4$ & MDKA2246 & Oct, $19-2015$ & $10: 08: 23$ & Closed & $\begin{array}{l}\text { There was an issue } \\
\text { with the backhaul } \\
\text { IDM got stuck }\end{array}$ & $\begin{array}{l}\text { Oct-19-2015 } \\
11: 30: 43\end{array}$ \\
\hline 2195573 & $\mathrm{P} 2$ & MDKA2255 & Oct, $23-2015$ & $11: 08: 23$ & Closed & $\begin{array}{lll}\text { Sector } & \text { was } & \text { up } \\
\text { services } & \text { were } & \text { ok } \\
\text { Only } & \text { loss } & \text { of } \\
\text { visibility } & & \\
\end{array}$ & $\begin{array}{l}\text { Oct-23-2015 } \\
12: 30: 43\end{array}$ \\
\hline 2197159 & P3 & Dawn VPN & $\begin{array}{l}\text { Nov, } 17 \\
\text { 12:08:23 }\end{array}$ & - 2015 & Closed & $\begin{array}{lr}\text { Frequency } & \text { was } \\
\text { changed } & \text { from } \\
\text { Lahore end.End to E } \\
\text { ND }\end{array}$ & $\begin{array}{l}\text { Nov-17-2015 } \\
13: 30: 43\end{array}$ \\
\hline 2197696 & $\mathrm{P} 4$ & MDKA2050 & $\begin{array}{l}\text { Nov, } 19 \\
\text { 13:08:23 }\end{array}$ & - 2015 & Closed & $\begin{array}{l}\text { GPS was faulty and } \\
\text { it was replaced }\end{array}$ & $\begin{array}{l}\text { Nov-19-2015 } \\
14: 30: 43\end{array}$ \\
\hline 2199065 & P3 & $\begin{array}{l}\text { Nazimabad } \\
\text { router }\end{array}$ & $\begin{array}{l}\text { Nov, } 14 \\
\text { 14:08:23 }\end{array}$ & - 2015 & Closed & $\mathrm{AC}$ is issue & $\begin{array}{l}\text { Nov-14-2015 } \\
15: 30: 43\end{array}$ \\
\hline 2199173 & $\mathrm{P} 4$ & MDKA2196 & $\begin{array}{l}\text { Dec, } 13 \\
10: 08: 23\end{array}$ & - 2015 & Closed & $\begin{array}{l}\text { Site Controller Card } \\
\text { was Replaced }\end{array}$ & $\begin{array}{l}\text { Dec-13-2015 } \\
11: 30: 43\end{array}$ \\
\hline 2199180 & P3 & $\begin{array}{l}\text { Karachi Router } \\
\text { Environemental } \\
\text { Alarm }\end{array}$ & $\begin{array}{l}\text { Dec, } 27 \\
11: 08: 23\end{array}$ & - 2015 & Closed & $\begin{array}{l}\text { KHI P3 Karachi } \\
\text { Router } \\
\text { Environmental } \\
\text { Alarm }\end{array}$ & $\begin{array}{l}\text { Dec-27-2015 } \\
12: 30: 43\end{array}$ \\
\hline 2199201 & $\mathrm{P} 4$ & MDKA2045 & Jan, 18 - 2016 & $12: 08: 23$ & $\begin{array}{l}\text { Awaiting } \\
\text { Customer }\end{array}$ & $\begin{array}{l}\text { ATS Panel } \\
\text { issue.Sitedoesnot } \\
\text { shift to Genset }\end{array}$ & $\begin{array}{l}\text { Jan-18-2016 } \\
13: 30: 43\end{array}$ \\
\hline 2199301 & $\mathrm{P} 4$ & MDKA2196 & Feb, 17 - 2016 & 14:08:23 & Closed & ODU was replaced & $\begin{array}{l}\text { Feb-17-2016 } \\
15: 30: 43\end{array}$ \\
\hline 2199318 & P4 & MDKA2245 & $\begin{array}{l}\text { Mar, } 03 \\
\text { 15:08:23 }\end{array}$ & - 2016 & Resolved & $\begin{array}{l}\text { Issue is under } \\
\text { observation }\end{array}$ & $\begin{array}{l}\text { Mar-03-2016 } \\
16: 30: 43\end{array}$ \\
\hline 2199919 & $\mathrm{P} 4$ & MDKA2236 & $\begin{array}{l}\text { Mar, } 16 \\
\text { 16:08:23 }\end{array}$ & $\begin{array}{l}-2016 \\
\end{array}$ & Closed & ATS Panel issue & $\begin{array}{l}\text { Mar-16-2016 } \\
17: 30: 43\end{array}$ \\
\hline 2199939 & P4 & $\begin{array}{l}\text { Ufone DHA } \\
\text { MDKA2042 }\end{array}$ & $\begin{array}{l}\text { Apr, } 18 \\
\text { 17:08:23 }\end{array}$ & - 2016 & Closed & $\begin{array}{l}\text { MTU size changes } \\
\text { to } 1400 \text { (RCA was } \\
\text { given again }\end{array}$ & $\begin{array}{l}\text { Apr-18-2016 } \\
\text { 18:30:43 }\end{array}$ \\
\hline 2199985 & $\mathrm{P} 4$ & CMPAK & Jul, 21 - 2016 & $21: 08: 23$ & $\begin{array}{l}\text { Awaiting } \\
\text { Customer }\end{array}$ & $\begin{array}{l}\text { Site is intentronally } \\
\text { down.SR is awaiting } \\
\text { to track it }\end{array}$ & Jul-21-2016 22:30:43 \\
\hline 2200004 & $\mathrm{P} 4$ & MDKA2165 & $\begin{array}{l}\text { Aug, } 17 \\
22: 08: 23\end{array}$ & - 2016 & Closed & $\begin{array}{l}\text { ATS Panel } \\
\text { issue.Sitedoesnot } \\
\text { shift to Genset }\end{array}$ & $\begin{array}{l}\text { Aug-17-2016 } \\
23: 30: 43\end{array}$ \\
\hline 2200004 & $\mathrm{P} 4$ & MDKA2236 & $\begin{array}{l}\text { Aug, } 29 \\
09: 12: 52\end{array}$ & - 2016 & Closed & $\begin{array}{l}\text { ATS Panel } \\
\text { issue.Sitedoesnot } \\
\text { shift to Genset }\end{array}$ & $\begin{array}{l}\text { Aug-29-2016 } \\
10: 11: 13\end{array}$ \\
\hline 2200062 & $\mathrm{P} 2$ & $\begin{array}{l}\text { Karachi } \\
\text { Nazimabad } \\
\text { Router }\end{array}$ & Sep, $14-2016$ & $10: 12: 52$ & Closed & ATS Panel issue & $\begin{array}{l}\text { Sep-14-2016 } \\
11: 11: 13\end{array}$ \\
\hline 2200137 & $\mathrm{P} 4$ & MDKA2151 & Sep, $18-2016$ & $11: 12: 52$ & Closed & $\begin{array}{l}\text { Site was rebooted at } \\
\text { due to DHCP script } \\
\text { running }\end{array}$ & $\begin{array}{l}\text { Sep-18-2016 } \\
12: 11: 13\end{array}$ \\
\hline 2200284 & $\mathrm{P} 4$ & MDKA2430 & Oct, $03-2016$ & $13: 45: 22$ & Resolved & $\begin{array}{l}\text { MTU size changes } \\
\text { to } 1400 \text { (RCA was } \\
\text { given again }\end{array}$ & $\begin{array}{l}\text { Oct-03-2016 } \\
14: 38: 13\end{array}$ \\
\hline 2200312 & $\mathrm{P} 4$ & $\begin{array}{l}\text { Arwentech } \\
\text { VPN }\end{array}$ & Oct, 04 - 2016 & $14: 45: 22$ & $\begin{array}{l}\text { Awaiting } \\
\text { Customer }\end{array}$ & $\begin{array}{l}\text { Issue is under } \\
\text { observation }\end{array}$ & $\begin{array}{l}\text { Oct-04-2016 } \\
15: 38: 13\end{array}$ \\
\hline 2200579 & P3 & Air Port Router & Oct, 07 - 2016 & $15: 45: 22$ & Closed & $\begin{array}{l}\text { Temperature is } \\
\text { normal }\end{array}$ & $\begin{array}{l}\text { Oct-07-2016 } \\
16: 38: 13 \\
\end{array}$ \\
\hline
\end{tabular}

KPI Reporting Sheet

Nationwide Monitoring: 


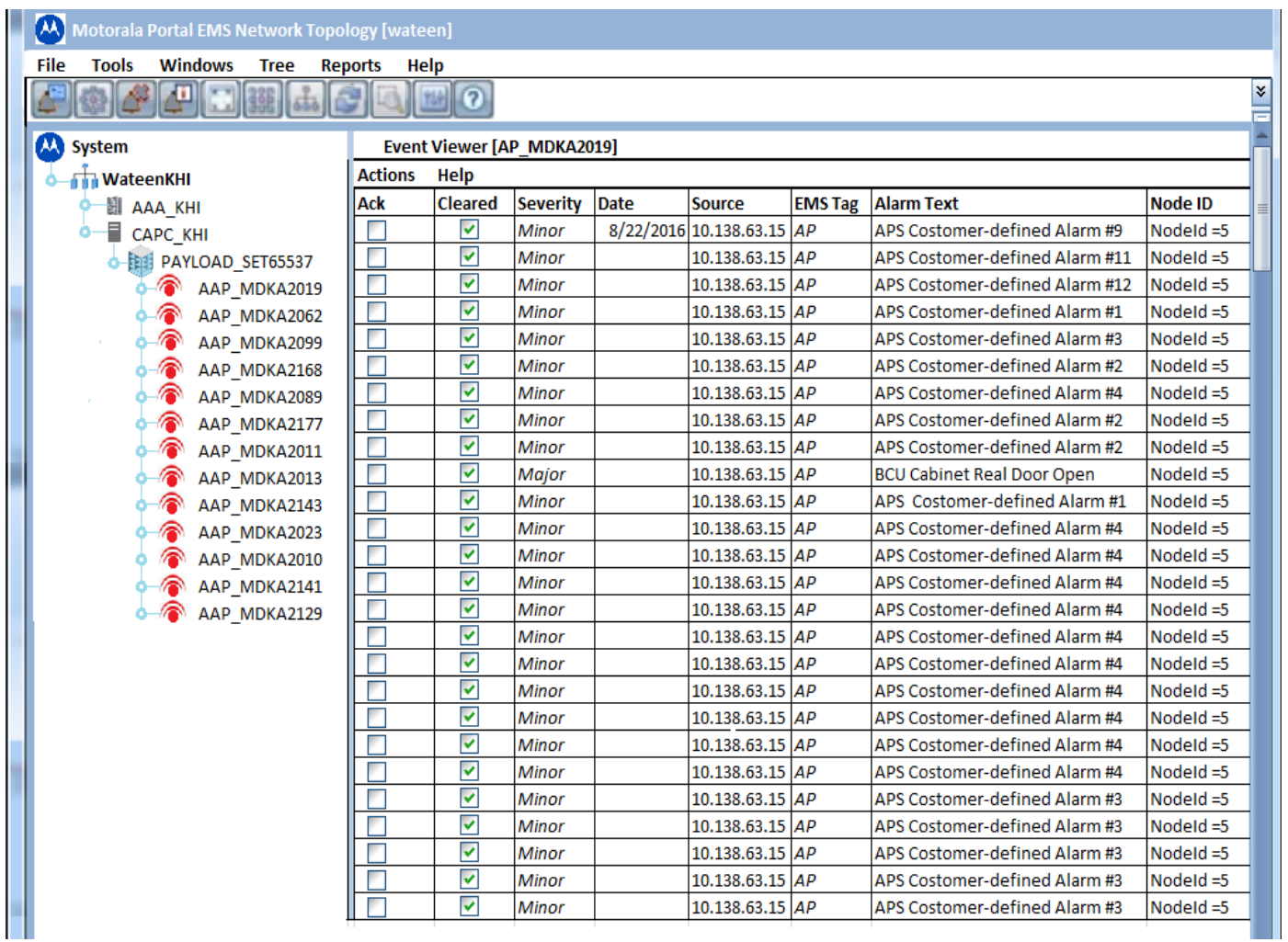

Reference: Real world MOTOROLA Portal EMS Network Topology [Wateen] snap shot from wateen nationwide network portal

\section{WiMAX signals through MOTOWI ${ }^{4}$ :}

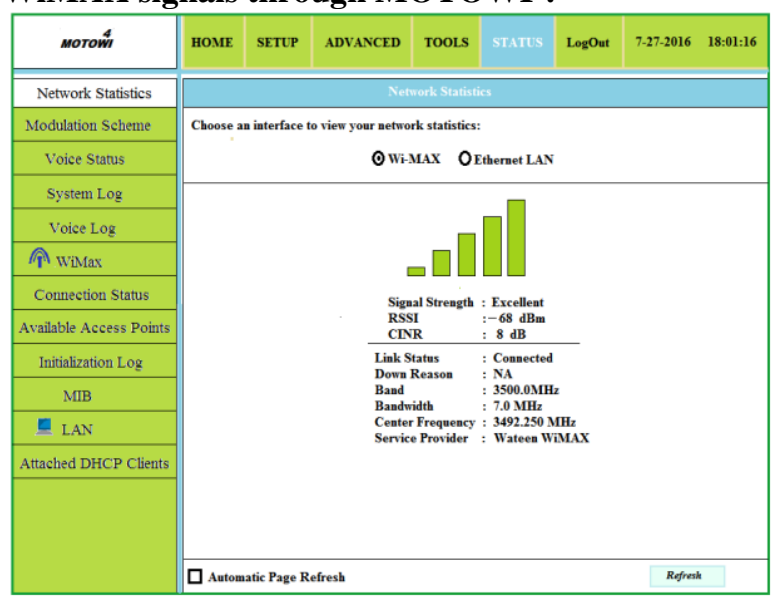

Reference: Real Testing and Analysis Snap Short For Diagnostic of WiMAX signals through MOTOWI ${ }^{4}$ Nationwide Field Cluster Points at Wateen Network
Wateen Karachi Network:

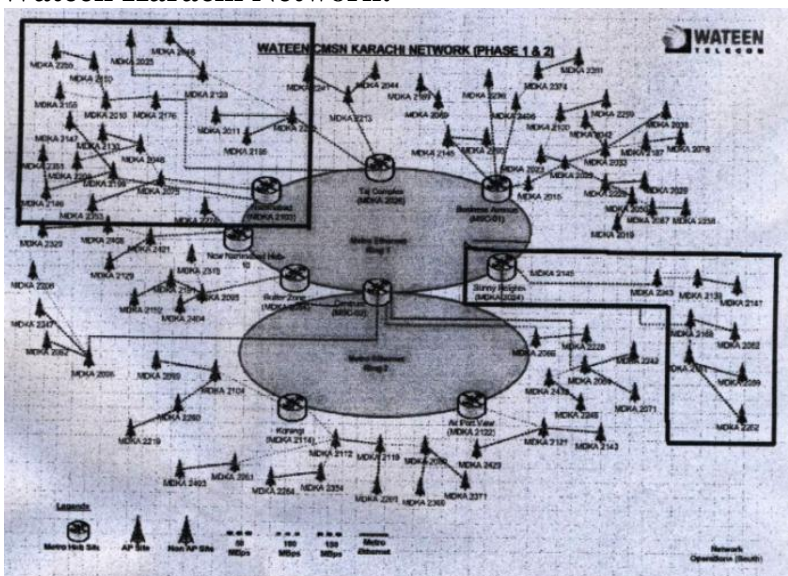

Reference: Phase 1 \& 2 CMSN Real Wateen Karachi Network Diagram from Manual 


\begin{tabular}{|c|c|c|c|c|c|c|c|c|c|c|c|c|c|c|}
\hline S. No. & Name & Long. & Lat. & Parent Sector & Frequency & Preamble Index & RSSI & CINR & Mod DL & Mod UL & Speed DL & Speed UL & Latency & Jitter \\
\hline & & & & & & & & & & & & & & \\
\hline & & & & & & & & & & & & & & \\
\hline 3 & KHI3 & 66.9985 & 24.9151 & MDKA2199_A & 3460.75 & 16 & -85 & 4 & QPSK & QPSK & $788 \mathrm{Kbps}$ & $98 \mathrm{Kbps}$ & 63 & 61 \\
\hline 14 & KHI14 & 66.9974 & 24.9017 & MDKA2199_C & 3492.25 & 82 & -94 & 5 & QPSK & QPSK & $769 \mathrm{Kbps}$ & $98 \mathrm{Kbps}$ & 75 & 70 \\
\hline 11 & KHI11 & 66.9883 & 24.9546 & MDKA2320_A & 3460.75 & 16 & -99 & 2 & QPSK & QPSK & $550 \mathrm{Kbps}$ & $110 \mathrm{Kbps}$ & 192 & 96 \\
\hline 2 & KHI2 & 66.9786 & 24.9097 & MDKA2351_B & 3560.75 & 49 & -90 & 4 & QPSK & QPSK & $998 \mathrm{Kbps}$ & $134 \mathrm{Kbps}$ & 65 & 70 \\
\hline 117 & KHI117 & 66.967 & 24.9094 & MDKA2351_D & 3592.25 & - & -83 & 13 & 16 QAM & QPSK & $1.90 \mathrm{Mbps}$ & $1.17 \mathrm{Mbps}$ & 67 & 11 \\
\hline 8 & KHI8 & 66.9907 & 24.9106 & MDKA2147_B & 3560.75 & 53 & -80 & 13 & 16 QAM & 16 QAM & $1.32 \mathrm{Mbps}$ & $0.43 \mathrm{Mbps}$ & 67 & 60 \\
\hline 9 & KHI9 & 66.9759 & 24.9155 & MDKA2147_D & 3592.25 & 23 & \begin{tabular}{|l|}
-87 \\
\end{tabular} & 8 & QPSK & QPSK & $615 \mathrm{Kbps}$ & $114 \mathrm{Kbps}$ & 82 & 69 \\
\hline 6 & KHI6 & 66.9972 & 24.9367 & MDKA2130_A & 3460.75 & 24 & -78 & 17 & 64 QAM & QPSK & $1.56 \mathrm{Mbps}$ & $998 \mathrm{Kbps}$ & 65 & 70 \\
\hline 10 & KHI10 & 66.9916 & 24.9275 & MDKA2130_C & 3492.25 & 90 & -84 & 15 & QPSK & QPSK & $540 \mathrm{Kbps}$ & $160 \mathrm{Kbps}$ & 58 & 67 \\
\hline 148 & KHI48 & 66.9843 & 24.9359 & MDKA2130_D & 3592.25 & 27 & -79 & 14 & 16 QAM & QPSK & $845 \mathrm{Kbps}$ & $200 \mathrm{Kbps}$ & 80 & 67 \\
\hline 13 & KHI13 & 67.0138 & 24.9135 & MDKA2353_C & 3492.25 & 90 & -89 & 4 & QPSK & QPSK & $205 \mathrm{Kbps}$ & $112 \mathrm{Kbps}$ & 64 & 123 \\
\hline \multicolumn{15}{|c|}{ Gulshan-e-Iqbal Cluster } \\
\hline 91 & KHI91 & 67.1589 & 24.9423 & MDKA2141_B & 3560.75 & 53 & \begin{tabular}{|l|}
-79 \\
\end{tabular} & 18 & 16 QAM & 16 QAM & $2.14 \mathrm{Mbps}$ & $1.21 \mathrm{Mbps}$ & 63 & 61 \\
\hline 107 & KHI107 & 67.1567 & 24.9332 & MDKA2141_C & 3492.25 & 86 & -70 & 22 & 64 QAM & 16 QAM & $4.4 \mathrm{Mbps}$ & $2.43 \mathrm{Mbps}$ & 77 & 61 \\
\hline 149 & KHI149 & 67.144 & 24.924 & MDKA2141_C & 3492.25 & 86 & -73 & 24 & 64 QAM & 16 QAM & $3.97 \mathrm{Mbps}$ & $1.81 \mathrm{Mbps}$ & 63 & 61 \\
\hline 82 & KHI82 & 67.0921 & 24.8951 & MDKA2168_D & 3592.25 & 27 & -63 & 24 & 64 QAM & 16 QAM & $3.68 \mathrm{Mbps}$ & $1.38 \mathrm{Mbps}$ & 63 & 61 \\
\hline 83 & KHI83 & 67.0988 & 24.8995 & MDKA2168_B & 3560.75 & 57 & -72 & 21 & 64 QAM & 16 QAM & $2.56 \mathrm{Mbps}$ & $447 \mathrm{Kbps}$ & 52 & 63 \\
\hline 78 & KHI78 & 67.0739 & 24.8862 & MDKA2059_D & 3592.35 & 27 & -85 & 13 & QPSK & QPSK & $660 \mathrm{Kbps}$ & $210 \mathrm{Kbps}$ & 60 & 63 \\
\hline 79 & KHI79 & 67.1075 & 24.8422 & MDKA2259_D & 3592.35 & 23 & -82 & 10 & QPSK & QPSK & $778 \mathrm{Kbps}$ & $223 \mathrm{Kbps}$ & 57 & 87 \\
\hline 77 & KHI77 & 67.0609 & 24.8982 & MDKA2252_A & 3492.25 & 20 & -61 & 28 & 64 QAM & QPSK & $1.10 \mathrm{Mbps}$ & 359 Kbps & 101 & 149 \\
\hline 74 & KHI74 & 67.0816 & 24.907 & MDKA2062_A & 3460.75 & 20 & -64 & 26 & 64 QAM & 16 QAM & $3.02 \mathrm{Mbps}$ & $1.38 \mathrm{Mbps}$ & 59 & 62 \\
\hline 76 & KHI76 & 67.0831 & 24.8989 & MDKA2062_C & 3492.25 & 86 & -78 & 16 & 16 QAM & 16 QAM & $3.31 \mathrm{Mbps}$ & $1.98 \mathrm{Mbps}$ & 61 & 60 \\
\hline 106 & KHI106 & 67.1404 & 24.935 & MDKA2141_D & 3592.25 & 23 & -80 & 19 & 64 QAM & 16 QAM & 4 Mbps & $2.07 \mathrm{Mbps}$ & 60 & 62 \\
\hline 150 & KHI150 & 67.1486 & 24.9283 & MDKA2141_C & 3492.25 & 86 & -90 & 10 & QPSK & QPSK & $1.02 \mathrm{Mbps}$ & $271 \mathrm{Kbps}$ & 68 & 60 \\
\hline 152 & KHI152 & 67.1204 & 24.9533 & MDKA2141_A & 3460.75 & 20 & -83 & 11 & QPSK & QPSK & $415 \mathrm{Kbps}$ & $286 \mathrm{Kbps}$ & 78 & 5 \\
\hline 153 & KHI153 & 67.1764 & 24.9416 & MDKA2141_B & 3560.75 & 53 & -74 & 26 & 64 QAM & 16 QAM & $2.66 \mathrm{Mbps}$ & $1.64 \mathrm{Mbps}$ & 119 & 4 \\
\hline
\end{tabular}

Difference between Karachi Central Cluster and Gulshan-e-Iqbal Cluster

Modulation Scheme for Karachi Central Cluster

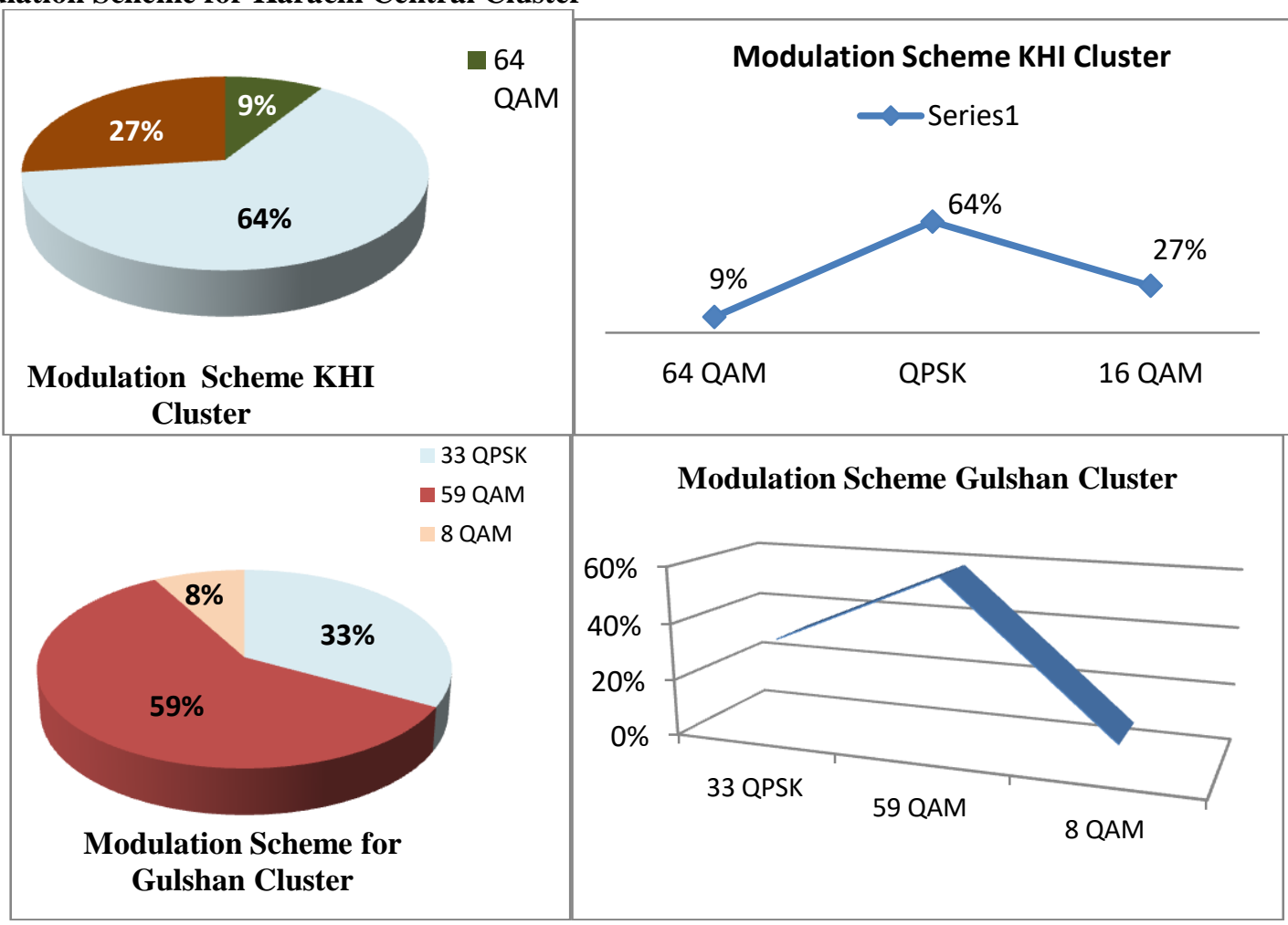


Modulation Scheme Chart Hyderabad Field
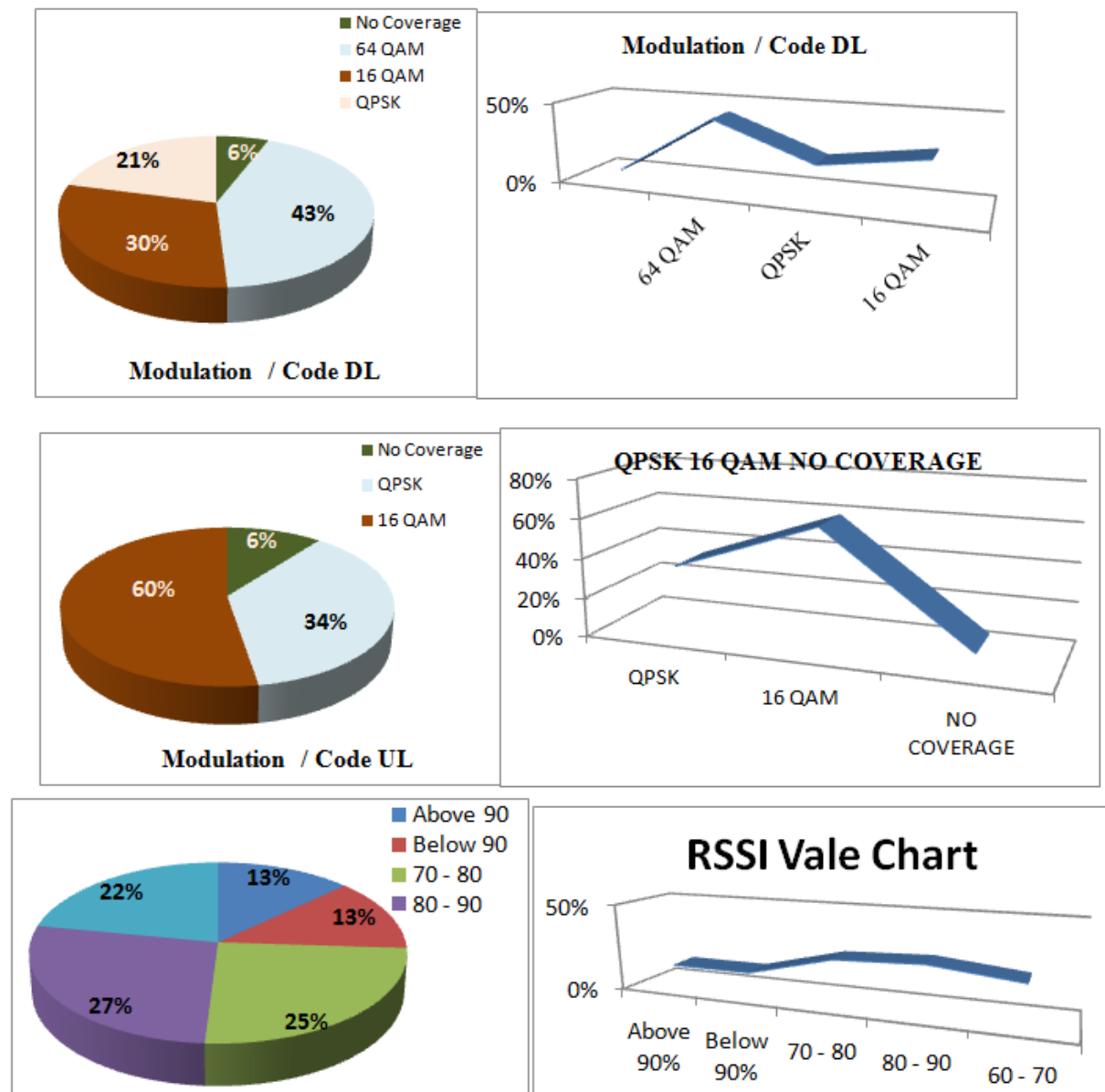

RSSI Value Chart Hyderabad Field

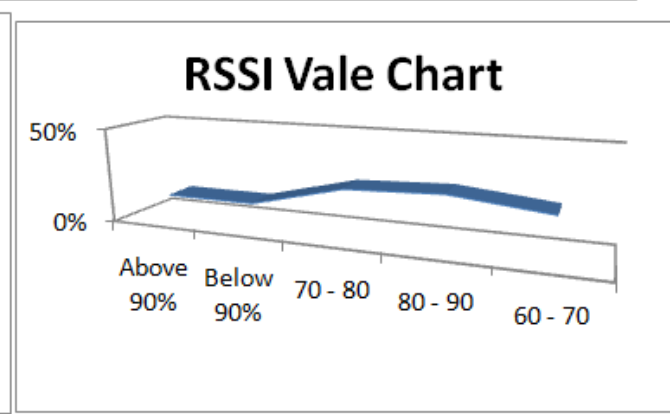

Modulation Scheme Chart Sukkur Field
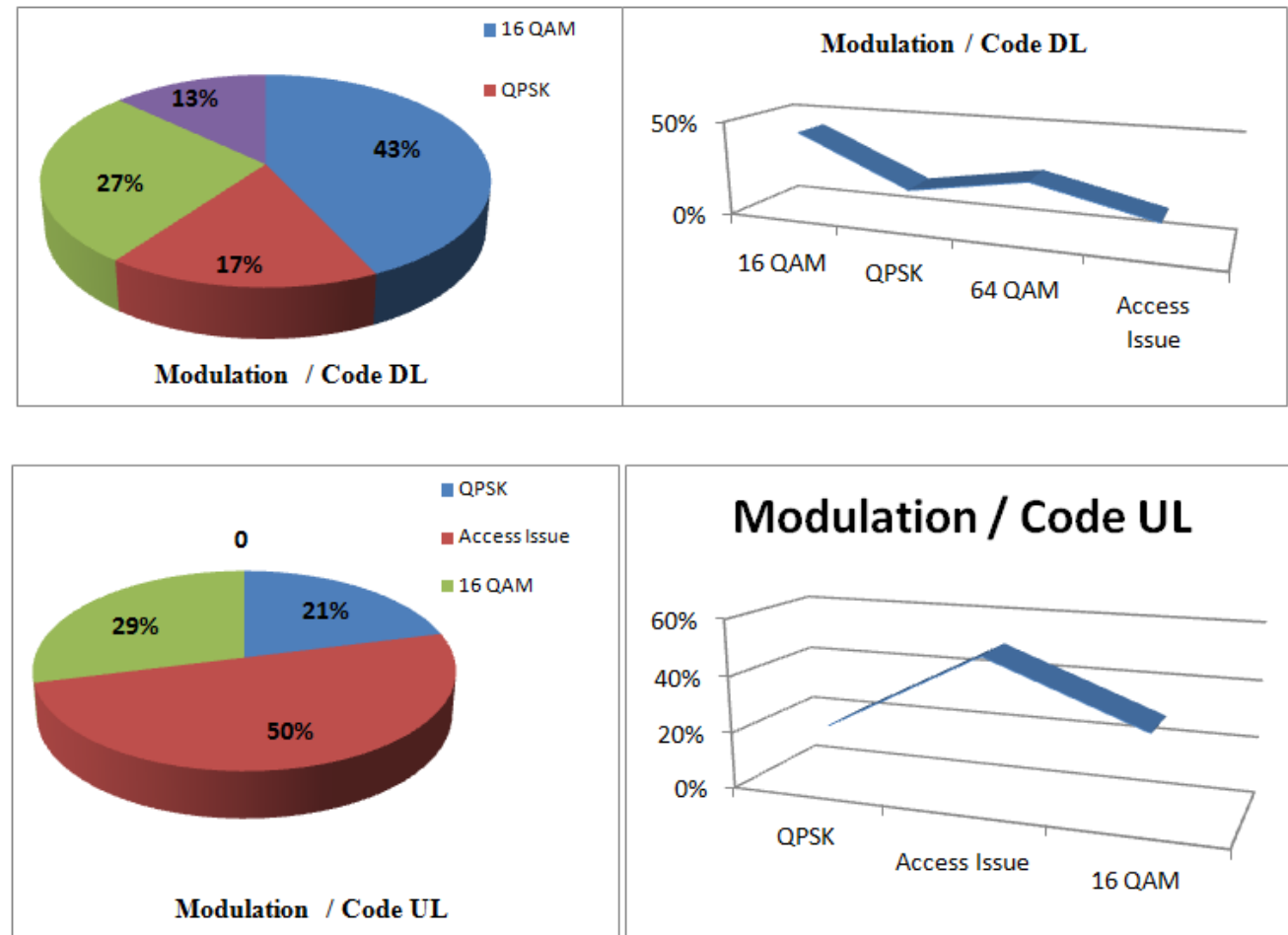

Modulation / Code UL

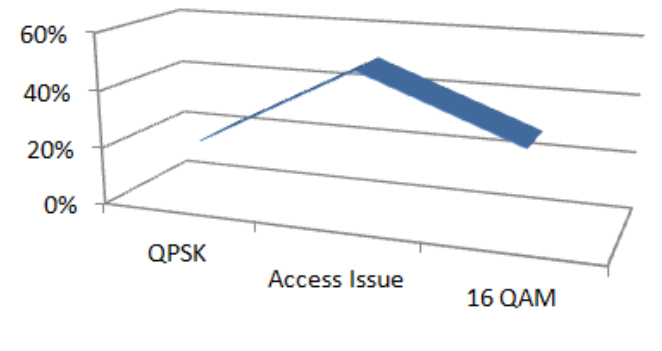




\section{Conclusion}

Most of the pointy in nationwide network monitoring we have to check the status of the DAP whether the site is up and down with the help of PEMS (Portal Element Management System) software. Mount or assembled all the nodes properly for given quality of service and mount right antenna on right places for the result as per 802.16 standard. Not everything aligns as good as per standard as well as bookish type of definition the ground situation is quite differing in some of cluster point's areas in south region. Somewhere vegetation may become one of the causes for affected on received signals, topography of the areas, loss connection or loosely assembled antennas (not fixed properly) and humidity. Obstacles of vegetation are become big challenge when heavy equipments transportation, the grower become hard face when the team go over there. Even I went some cluster point and want to tested for validation per standard or the service provider claim, I faces the same. The government and the service provider company have great responsibility to resolve this matter on the bases of high priority for monitoring or given strength signals as per standard. In this regard relation departments are working but it slower as per need for the progress of our country.

The majority of the point where tested around nationwide network monitoring diagnostic the weather is affected on the WiMAX signals also if the antenna is not properly mount or assembled then it also week signals or packet loss. If there are any engineering faults in it then it's not proper work as per need. The pollution is not effected on it but rain and oxygen when increase the $\mathrm{MHz}$. Actually heat is not effect on microwave but due to high temperature the moisture and the humidity can effect on it.

The signals strength was tested 10 to 15 meters coordinate in mostly cluster points in south region of Pakistan. The best result found in Gulshan-e-Iqbal Cluster which also known as Sunny Hieght Cluster but it will given more better results if counter part of antenna or booster will assembled on high rise buildings in south region.The moisture will effect on the received signals strength also the oxygen absorbed the signals too.

\section{Acknowledgements}

I have taken hard work in this project. However, it would not have been achievable without the kind prop up and help of many individuals and organization. I would like to broaden my sincere gratitude to all of them.I am exceedingly beholden to Dr. MEMOONA, Dr. MUHAMMAD WASIFand Engr. KHAN SARIM YASEENin favor of their supervision and stable direction as long as essential in order on the subject of work and the maintain in implementation of the work scheme.I would like to state my special thankfulness to industry persons for giving me such concentration and time.My thanks and appreciations also go to my colleague in developing the project and people who have enthusiastically helped me out with their abilities.

\section{References}

[1]. Arshad Wahab and Xu Jiadong. Design and performance analysis of asymmetric U-Slot Circular patch antenna for WiMAX and WLAN application, International Journal of Multimedia and Ubiquitous Engineering, 14(1), 2015, 1975-0080

[2]. AvniKhatkar, A Comprehensive Review on WiMAX Networks, International Journal of Innovations in Engineering and Technology, 3(3), 2014, $2319-1058$.

[3]. Ban A. Al-Omar, TahaLandolsi and A. R. Al-Ali, Evaluation of WiMAX technology in smart grid communications, Journal of Communications, 10(10), 2015,1796-2021.

[4]. Chang-tseh Hsieh, Bill Manduca and Binshan Lin, Information technology and six sigma implementation, Journal of Computer Information Systems, 47(4), 2007, 2380-2057.

[5]. Gurmandeepkaur and Navneet Kaur, Dissect the performance of network layer routing protocols (AODV, DSDV and ZRP) for video streaming over Worldwide Interoperability of Microwaves Access (WiMax), International Journal of Applied Engineering Research, 11(10), 2016, 0973-4562.

[6]. Hussein M. Hathal, Performance Evaluation of Different Modulation Coding for Scheduling Services over VoIP in WiMAX Network, SAUSSUREA Multidisciplinary International Peer Reviewed Journal Indexed in Web of Science ,6(1), 2016, $0373-2525$.

[7]. Ho-Kyung Son, Jong-Ho Kim, Che-Young Kim, Analysis of radio interface through ducting for $2.5 \mathrm{GHz}$ WiMax Service, JOURNAL OF THE KOREAN INSTITUTE OF ELECTROMAGNETIC ENGINEERING AND SCIENCE, 12(1), 2012, $2234-8395$.

[8]. Hardeep Kaur and M. L. Singh, Performance analysis of concatenated RS-CC code for WiMAX system using QPSK, International Journal of Innovations \& Advancement in Computer Science,4(Special Issue), 2015, 2347 - 8616.

[9]. JuwitaMohd Sultan, GarikMarkarian, Phillip Benachour, Integration of WiFi and WiMAX Service: Bandwidth optimization and traffic combination, International Journal Web Applications, 7(3), 2015, 0974-7729.

[10]. Joohan Lee, Juhho Lee and Sungkwon Park, Cross layer optimized architecture of MIBS over mobile WiMAX, Journal of Networking Technology, 6(2), 2015, 0974-8998.

[11]. Kamil PONGOT, Abdul Rani OTHMAN, Zahriladha ZAKARIA, Mohamad Kadim SUADI, Abdul Hamid HAMIDON, Azman AHMAD and Mohamad Tarmizy AHMAD, Design of triple-stage cascoded LNA amplifiers using inductive drain feedback (IDF) technique for WiMAX application, International Journal on Electrical Engineering and Informatics, 7(2), 2015, $2087-5886$.

[12]. Mahmood, Anzar, Nadeem Javaid, and SohailRazzaq, A review of wireless communications for smart grid, Renewable and Sustainable Energy Reviews, 41, 2015, 248-260.

[13]. Mohamed Ahmed Alamein, Wilson Jeberson and Ahmed M HuseinShabani. (2015) Hybrid resource allocation and scheduling technique for WiMAX networks, International Journal of Computer and Information Technologies, 3(2), $2015,2345-3877$.

[14]. Md. Shah Alam and KaziTanvir Ahmed, Performance analysis of fixed WiMax in metropolitan area, International Journal of Electronics and Communication Engineering, 5(3), 2012, 0974-2166.

[15]. NoudjoudKahya ,NaciraGhoualmi and Pascal Lafourcade, Formal Analysis of Key Management in 802.16e, International Journal of Computer Science and Network Security, 16(8), 2016, 1738-7906. 
[16]. OmprakashKaiwartya, Abdul Hanan Abdullah, Yue Cao, Ayman Altameem, MukeshParsad, Chin-Teng Lin and Xiulei Liu, Internet of vehicles: motivation layered architecture network model challenges and future aspects, IEEE Access, 4, 2016, $2169-3536$.

[17]. Rajkanwar Singh and Sarabjit Singh. (2016) Evaluation of WiMAX 802.16 technology performance by evaluating the bit error rate (BER) of OFDM physical layer under different modulation schemes and channels conditions, International journal of innovative research in electrical electronics instrumentation and control engineering, 4(2), 2016, 2321 - 2004.

[18]. Shahid Hussain, Muhammad Naeem Khan and Muhammad Ibrahim, A Security Architecture for Wimax Networks, International Journal of Computer Applications, 50(9), 2012, 0975 - 8887.

[19]. Shuang Song and Biju Issac, Analysis of WIFI and WiMAX and Wireless Network Coexistence, International Journal of Computer Networks \& Communications, 6(6), 2014, 0974-9322.

[20]. S. Srivisshudhanan, Analysis of QoS in WiMAX Network, International Journal of advancement in engineering technology management \& applied science, 2(5), 2015, 2349-3224.

[21]. Shuming T. Wang, Yen-Fu Chen, Rey-Chue Hwang, Shen-Whan Chen*, A Novel Reconfigurable Polarization Dual-band Patch Antenna for WLAN and WiMAX Systems, World Journal of Research and Review, 2(3), 2016, 2455-3956

[22]. T. Sankar and Dr. Prabakaran, Minimum spanning tree based minimized data handover delay in challenged environment for WiMAX Networks, International Journal of Applied Engineering Research, 1(1), 2016, 0973-4562.

[23]. Vikram Mehta and Dr. Neena Gupta, Performance analysis of QoS parameters for WiMAX Network, International Journal of Engineering and Innovative Technology, 1(5), 2012, 2277-3754.

[24]. Y.H. Lee, H.W. Tseng, W.C. Lee, J.Y. Lin, Y.G. Jan and H.W. Tsao, The measurement and analysis of WiMAX base station signal coverage, Progress in electromagnetics Research C, 25, 2012, 1937-8718.

[25]. Zhang, Qi; Dam, H.,WiMAX network performance monitoring \& optimization, I E EE - I F I P Network Operations and Management Symposium, 2008,1542-1201. 